\title{
Food Habits of Nilgai Antelope in Texas
}

WILLIAM J. SHEFFIELD

\begin{abstract}
A 2-year food habit study of the nilgai antelope (Boselaphus tragocamelus) and its forage selections compared with white-tailed deer (Odocoileus virginianus) and cattle was conducted in south Texas. Rumen analyses of 79 nilgai and 40 deer, collected on various feeding sites, and bite studies on the same sites using two captive nilgai and a trained steer showed no significant difference $(P>0.05)$ in forage classes taken between the 2 methods. Nilgai preferred to feed on large open areas interspersed with cover and ponded water. They were grazers, their average diet consisting of $60 \%$ grasses, $25 \%$ forbs, and $15 \%$ browse. They augumented the nutritive level of their basic diet by selecting nutritious plant parts and changing their selections as the parts appeared, waned, and fuctuated in quality with the seasons. When food was scarce, nilgai ate more browse, dead vegetation, and dry dung of large herbivores. The quality and quantity of their forage was within the levels published for cattle and North American big game. They maintained a feeding role intermediate between cattle, which used mainly grass, and deer, which used forbs heavily. When food supply and variety was low, nilgai competed strongly with cattle for grass and deer for forbs. The 3 species seem compatible where there is good variety of browse and herbage, and control of their respective numbers.
\end{abstract}

Nilgai antelope, native to India, are one of several species of big game exotics that have successfully established themselves as freeranging animals in Texas (Ramsey 1969, Sheffield et al. 1971). Nilgai were released in this country without a preliminary investigation of their ecological compatibility. This study was done to learn of their food habits and of the feeding competition among nilgai, cattle, and white-tailed deer. It was conducted between 1969 and 1971 on King Ranch in south Texas, and is the first food habits study on nilgai in North America. No subsequent studies have been found in the literature.

\section{Study Area}

The largest population of nilgai in this country (about 4500

Sincere appreciation is expressed for partial funding by the Caesar Kleberg Research Program in Wild life Ecology, Department of Wild life and Fisheries Sciences, Texas A\&M University, and to Dr. Jack M. Inglis, Department of Wildlife and Fisheries Sciences, and Dr. Fred E. Smeins, Department of Range Science, Texas A\&M University, for comments on the manuscript.

Manuscript received August 15, 1981.

ITaxonomic nomenclature is according to Gould (1975). animals) exists on the Norias Division of King Ranch, where nilgai were released in the 1930's. Norias is a 94,000-ha cattle ranch located in Kenedy County, Texas adjacent to Laguna Madre on the Gulf of Mexico (Fig. 1).

The topography is generally undulating with slopes varying from 0 to 15\% (Franki 1960). Elevations range from flats $3 \mathrm{~m}$ above sea level to sand dunes $21 \mathrm{~m}$ above sea level (U.S. Geological Survey 1952,1956 ). Soils are infertile, droughty, weakly alkaline to slightly acid, underlain by firm or permeable clays, and have a low phosphorus content (Davis 1952, Reynolds et al. 1953, Gould 1975).

Climatological data (Long 1968; U.S. Weather Bureau 1969, 1970,1971 ) show that the region is semiarid with an average annual rainfall of $68 \mathrm{~cm}$ and an evaporation rate of $140 \mathrm{~cm}$. The mean annual temperature is $23^{\circ} \mathrm{C}$, with extremes of over $38^{\circ} \mathrm{C}$ during July and August and lows of $-7^{\circ} \mathrm{C}$ during January. High afternoon winds occur most of the year. Frost-free days average 330 per year. Short seasonal droughts are common and prolonged droughts occur in the region. Heavy dews also occur and at times are the principal source of moisture.

The Norias Division has live oak (Quercus virginiana) forests interspersed with mesquite (Prosopis glandulosa) flats and small openings, oak mottes, solid mesquite stands, ephemeral ponds on brackish flats, natural openings, and rootplowed rangeland. Common native grasses include species of Setaria, Panicum, Paspalum, and Aristida. Buffelgrass (Cenchrus ciliaris) and bermudagrass (Cynadon dactylon) are abundant introduced grasses. Moist sites have species of Carex, Cyperus, Spartina, and Juncus. Cacti (Opuntia spp.), croton (Croton spp.), and ragweed (Ambrosia psilostachya) are prominent plants classified as forbs for this study.

On the rootplowed land brushrows are spaced approximately 1 $\mathrm{km}$ apart and serve as shelter for livestock, feral hogs (Sus sp.) and wildlife such as the nilgai, white-tailed deer, collared peccary (Tayassu tajacu), coyote (Canis latrans), bobcat (Lynx rufus), and bobwhite quail (Colinus virginianus). Large numbers of shorebirds, wading birds and migratory waterfowl also frequent the area.

\section{Methods}

\section{Study Area Location}

The population structure and ecological distribution of nilgai were determined by helicopter censuses and ground checks (Sheffield et al. 1971). The study area was established on 16,000 ha in the southeast section of Norias encompassing the Cristal, Rosita, and 


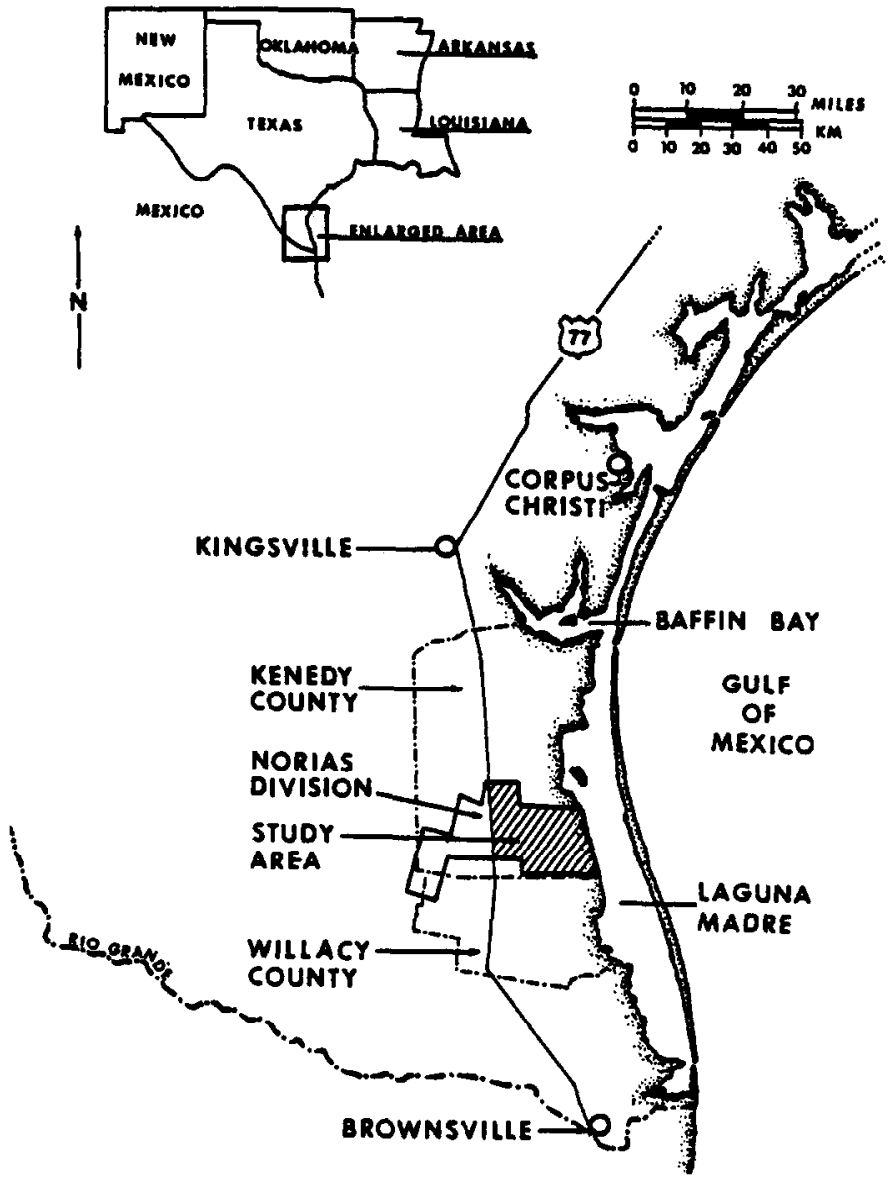

Fig. 1. Study area on the Norias Division, King Ranch, Inc.

southwest part of the Saltillo pastures, where nilgai were consistently high in number.

\section{Food Analyses}

Rumen analyses of wild nilgai and deer, bite studies with 2 trained nilgai and a steer, and field observations were made to determine food habits. Nilgai were collected throughout the 2-year study. During the second year, a nilgai and deer were collected on each hunt. Seventy-nine nilgai and 40 deer were taken. The collections were made weekly by shooting specimens with a highpowered rifle during their diurnal feedings. They were necropsied in the field for rumen analyses and related studies. The entire rumens were weighed, volumed, and $500 \mathrm{ml}$ samples of their content were frozen for composition and nutritional analyses. The point frame method was used for rumen analyses (Chamrad and Box 1964). The order of preference of bite study animals for plant species was calculated by a modification of the rumen analysis formula as follows:

$$
\text { Preference indices }=\frac{\% \text { bites per plant species } \times \% \text { freq. }}{\text { plant occurrence }}
$$
where,

$$
\% \text { Available vegetation }=\frac{\begin{array}{l}
\% \text { of ground covered by } \\
\text { plant species selected }
\end{array}}{\% \text { available vegetation cover }}
$$

Each bite study animal was allowed to feed 1 hour in the same location and during the same time of day where each wild specimen had been feeding.

Results from both the rumen analyses and bite studies were broken down for each collected specimen and study animal performance by animal species, sex, age class, feeding time, season, cover type; and vegetation class, species (when identifiable), and plant parts taken.

\section{Available Vegetation}

The percent of ground cover within reach of nilgai (up to $2.4 \mathrm{~m}$ high) provided by each plant species was measured by a technique modified from Daubenmire (1959). On each animal collection site 20 plots $1 \mathrm{~m}^{2}$, spaced $20 \mathrm{~m}$ apart were surveyed from the spot of kill and backtracking along the specimen's feeding route. Seasonal periods were defined as: spring(Mar.-May); summer (June-Aug.); fall (Sept.-Nov); and winter (Dec.-Feb.).

\section{Diet Quality}

The food selections of bite study animals were hand simulated. Hand picked components were kept separate by species and frozen in plastic bags until analyzed. The components were oven dried, at $27^{\circ} \mathrm{C}$ for 24 to 48 hours, ground to powder in a laboratory mill, and combined by weight percentages according to the percentage composition of the actual animal selections.

Analyses were made of the levels of crude protein, calcium, phosphorus, moisture (following the procedures of the AOAC 1970) and cell wall (Van Soest and Wine 1967) in hand simulated diets and rumen samples. The levels were compared with levels published for certain big game and cattle as an index of the quality of diet maintained by nilgai.

\section{Diet Quantity}

The amount of forage nilgai removed from the range daily was estimated based on the dry weight of rumen ingesta, number of feedings in 24 hours, and an allowance for rate of passage of ingesta from the rumen. The estimate was made for each age and sex classes. A passage rate was extrapolated from Mautz and Petrides (1971). The number and population structure of nilgai was derived from the census mentioned earlier. The formula used for calculating quantity was:

kg D.W.

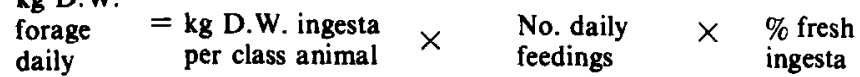

\section{Results and Discussion}

\section{Preferred Feeding Range}

The rootplowed zones with scattered ponds and cover were the preferred feeding range for nilgai. Nilgai used ponds for drinking and fed on plants that the pond water was sustained. The principal source of browse Norias nilgai consumed came from edges and woody patches associated with rootplowed areas.

The large woodland areas lacked successional stages of vegetation provided the quantity and diversity nilgai prefer, and lacked sufficiently large openings for long distance visibility and easy flight. Dinerstein (1979) found that nilgai in Nepal preferred subclimax habitat with vegetation in middle successional stages. They spent much of their time on open short grassland/savanna rather than in the contiguous tall grass-rivering forests where visibility was poorer, escape more difficult, and predators numerous. This was comparable to nilgai use of rootplowed and woodland areas on Norias.

\begin{tabular}{|c|c|c|c|c|}
\hline \multirow[b]{2}{*}{ Class } & \multicolumn{2}{|c|}{ Nilgai } & \multirow{2}{*}{$\begin{array}{c}\text { Deer } \\
\text { rumen } \\
\text { analysis (3) }\end{array}$} & \multirow{2}{*}{$\begin{array}{c}\text { Steer } \\
\text { bite } \\
\text { study (4) }\end{array}$} \\
\hline & $\begin{array}{c}\text { Rumen } \\
\text { analysis (1) }\end{array}$ & $\begin{array}{c}\text { Bite } \\
\text { study (2) }\end{array}$ & & \\
\hline Grasses & 60 & 65 & 23 & 95 \\
\hline Forbs & 25 & 26 & 60 & 3 \\
\hline Browse & 6 & 6 & 13 & 1 \\
\hline Mesquite beans & 9 & 3 & 4 & 1 \\
\hline
\end{tabular}

Table 1. Percentages of forage classes consumed by nilgai', deer, and a steer, Norias Division, King Ranch, Texas.

I Wild nilgai $=$ rumen analysis; trained nilgai $=$ bite study .

1 vs. 2 No significant difference $(P>0.05)$.

1 vs. 3 Significant difference $(P<0.01)$.

1 vs. 4 Significant differences $(P<0.01)$ 
Table 2. Percentages of forage classes consumed by nilgai by sex and age classes, Norlas Division, King Ranch.!

\begin{tabular}{lcccc}
\hline \hline & & \multicolumn{2}{c}{ Percent of forage classes } \\
\cline { 2 - 5 } Nilgai & Grasses & Forbs & Browse & Mesquite beans \\
\hline Adult males (1) & 60 & 27 & 4 & 9 \\
Subadult males (2) & 57 & 30 & 5 & 14 \\
Trained male calf (3) & 52 & 33 & 11 & 3 \\
Adult females (4) & 54 & 23 & 12 \\
Subadult females (5) & 68 & 21 & 8 & 1 \\
Trained subadult female (6) & 71 & 24 & 4 & 1 \\
\hline
\end{tabular}

IPercentages for trained nilgai determined by bite studies;

${ }^{2}$ Percentages for wild nilgai determined by rumen analysis.

1 vs. 3 Significant difference $\left(x^{2}, p<0.01\right)$.

I vs. 4 Significant difference $\quad\left(x^{2}, p<0.01\right)$.

4 vs. 6 Significant difference $\quad\left(x^{2}, p<0.01\right)$

2 vs. 5 No Significant difference $\quad\left(x^{2}, p>0.05\right)$.

3 vs. 6 Significant difference $\quad\left(x^{2}, p<0.01\right)$

\section{Food Habits}

Of 265 plant species encountered 84 species were grasses, 166 forbs, and 15 browse. Nilgai used 167 species: 66 grass, 89 forb, and 12 browse. Herbage was $85 \%$ (60\% grasses, $25 \%$ forbs) of their diet (Table 1). Although nilgai did not use browse heavily (except mesquite beans used heavily when available), their seasonal use of certain browse was significant.

The greatest difference in selections between wild and the trained nilgai was greater use by wildings of mesquite beans and other items that require searching. The trained animals used less of these items perhaps because they had adequate nutrients in their artificial feed, were not as free to move about while feeding, and were not as experienced as wild feeders at finding specialty items. Nevertheless, the wild and trained nilgai fed similarly (Table 1). Buechner (1950) and Wallmo (1951), working with trained pronghorns (Antilocapra americana), and McMahan (1964), Watts (1964), and Wallmo and Neff (1970) working with white-tailed deer, found that study animals selected plants similar to those selected by their wild counterparts.

Adult female nilgai consumed less grass than adult males and subadults consumed more forbs than adults (Table 2). On an annual basis, the trained nilgai used 13 plant species to a high degree, 56 moderately, 98 lightly, and another 98 not at all (Table 3). The difference in amount and kind of food selected during morning and evening feedings was not significant $(P>0.05)$. Herbage consumed during morning feedings provided more moisture because of usual heavy morning dew.

\section{Seasonal Selections}

\section{Spring}

The greatest amount of nutritious growth for the year occurred in spring. Herbage sprouts, inflorescences and fruits were $43 \%$ of the nilgai diet. Nilgai made heaviest use of grass in spring when their diet was $74 \%$ grass, $21 \%$ forbs, and $5 \%$ browse (Fig. 2).
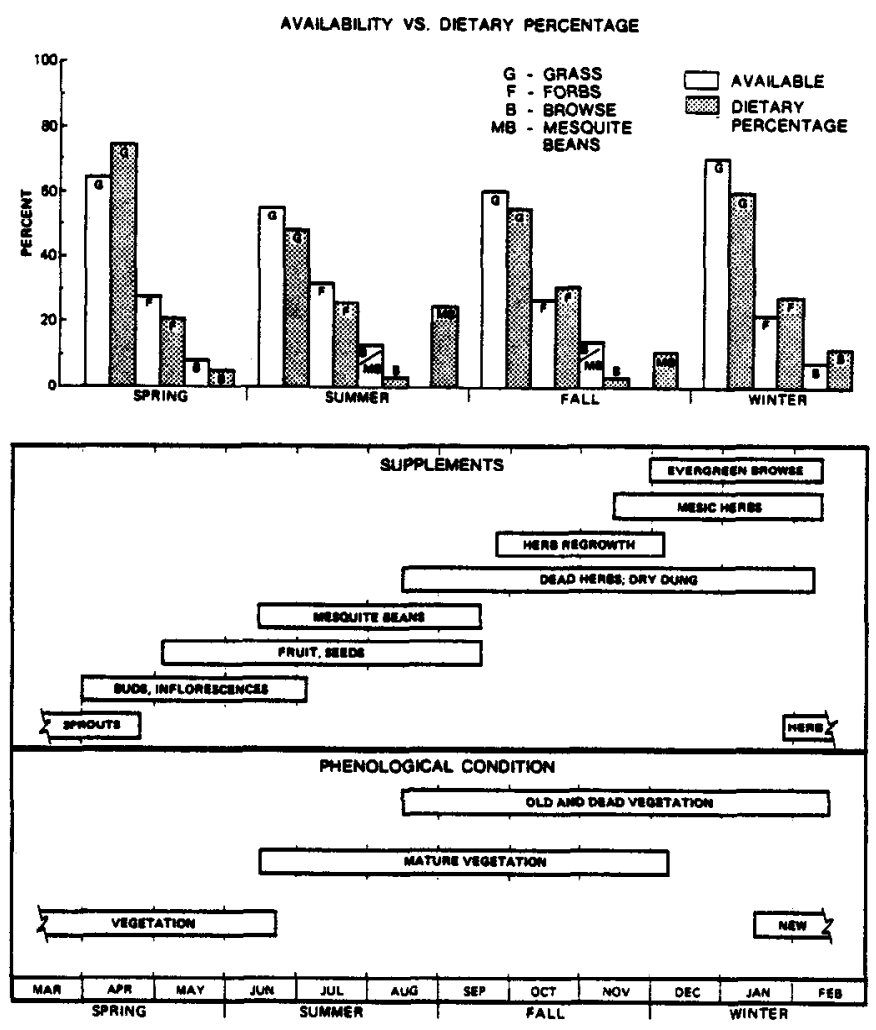

Fig. 2. Seasonal availability and nilgai dietary percentages of forage classes; nilgai supplements by principal periods of use; and general phenological condition of forage, Norias Division, King Ranch.

Table 3. Plant species used by trained nilgai on feeding sites from which wild nilgai were collected, Norias Division, King Ranch.

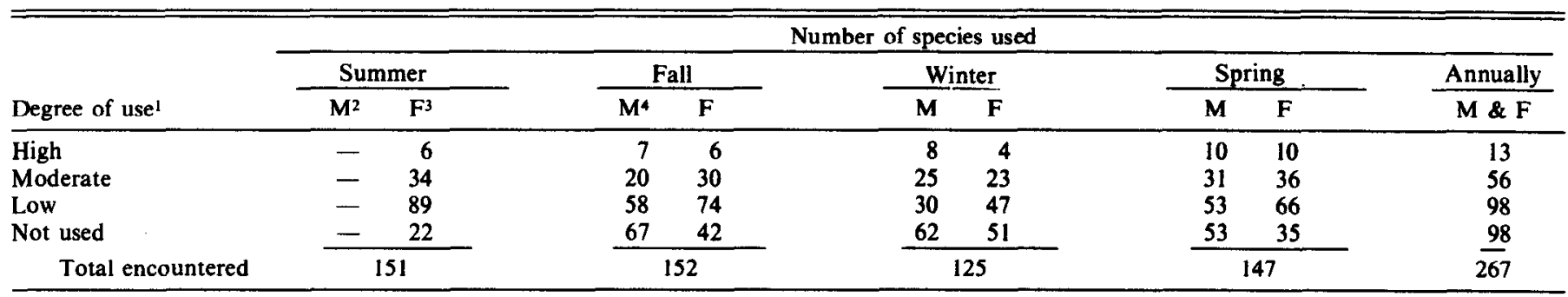

'High $-3 \%$ or more of feeding selections.

Modcrate -1 to $3 \%$ of fecding selections.

Low - Trace to $1 \%$ of feeding selections.

${ }^{2}$ Not in use during this period.

${ }^{3} \mathbf{F}$ - Trained female nilgai.

${ }_{4} \mathbf{N}$ - Trained male nilgai calf. 


\section{Summer}

Early summer had the greatest abundance and variety of vegetation for the year and nilgai diets became more varied. By midsummer, however, grazing pressure and hot, dry weather reduced the quantity and quality of herbaceous forage. Mesquite beans became available in June were heavily used by midsummer and constituted $23 \%$ of the overall summer diet. Available ground cover dropped from $89 \%$ (early summer) to $67 \%$ (late summer). From June through September nilgai made substantial use of seeds including those of mesquite, partridgepea (Cassia fasciculata), crotons, and nightshades (Solanum spp.). Summer diets became high in mature stems and leaves. Diets were $48 \%$ grasses, $26 \%$ forbs, $3 \%$ browse foliage, and $23 \%$ mesquite beans (Fig. 2).

\section{Fall}

In autumn, just before late season rains, the abundance and quality of grasses were lower than during any period except late winter. Mesquite beans remained a major dietary supplement (11\%) until mid-September, then diminished. Available herbage was mainly the lower portions of leaves and stems, which became $94 \%$ of plant parts eaten. When autumn rains induced a flush of herbaceous growth, nilgai resumed heavy use of upper parts of vegetation. Their overall fall diet was 55,31 , and $14 \%$ grasses, forbs, and browse (mesquite beans $11 \%$, foliage 3\%).

\section{Winter}

By midwinter ground cover dropped to $59 \%$. The composition of winter diets was 60,28 , and $12 \%$ grasses, forbs and browse, respec-
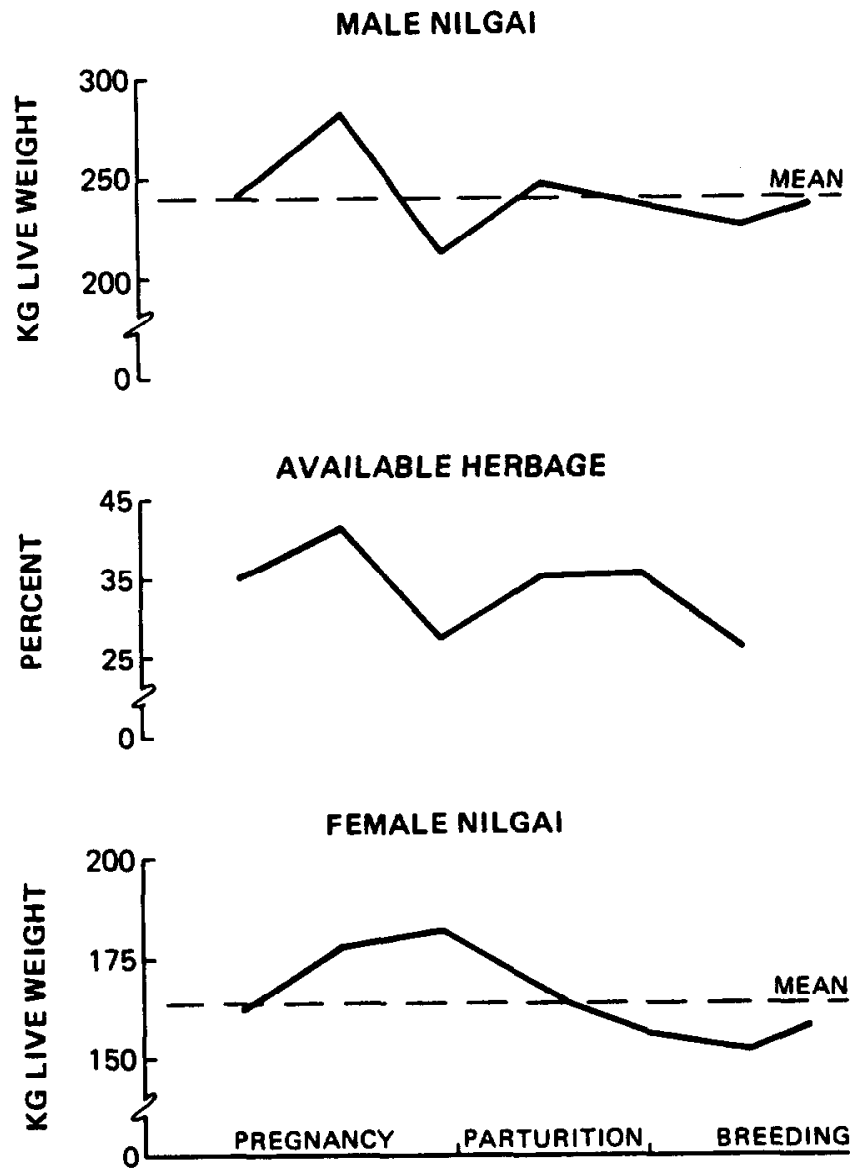

\begin{tabular}{llllll}
\hline MAR & MAY & JUL & SEP & NOV & JAN \\
\hline APR & JUN & AUG & OCT & DEC & FEB
\end{tabular}

Fig. 3. Average live weight of adult nilgai specimens compared with percent available herbage, Norias Division, King Ranch. Because of pregnancy, June-Aug. weight of females was not suppressed. tively. Sixty percent of plant parts taken were lower portions of leaves and stems (Fig. 2).

Despite the waning of green herbage, Panicum, Paspalum, Eleocharis, and Cyperus remained green throughout winter around ephemeral ponds where surface water gradually evaporated. Pondsite herbs made an important contribution to the supplementary items in winter diets.

Nilgai displayed poorer body condition in late winter than during other seasons. Increased breeding activity, colder temperatures, and a decline in the quality and quantity of food contributed to their poor condition. The weights of adult males correlated signiticantly $(p=0.05 ; r=0.345)$ with herbage availability alone. Weights of adult females did not correlate significantly $(p=0.051$; $r=0.229$ ) with available herbage because their weight fluctuations were influenced by pregnancy (Fig. 3).

\section{Diet Quality}

Simulated diets based on performances of the trained male nilgai calf revealed higher levels of crude protein, calcium, phosphorus, and moisture, and lower cell wall content than simulations based on the trained female nilgai or steer's performances (Fig. 4, 5). The more nutritious diet of the nilgai calf resulted from greater use of forbs and browse and less grass than the female or steer. The female's diet was more closely comparable to the average diet of wild nilgai (Tables 1, 2).

\section{Crude Protein}

Simulated diets contained a high of $15.6 \%$ crude protein in spring to lows in late spring and winter of $7.5 \%$ (average $10 \%$ ). Crude protein averaged $9 \%$ in rumen samples from 12 wild specimens collected throughout an annual cycle. Based on the findings from studies of steers by Cable and Shumway (1965), rumen samples were expected to test higher in protein than simulated diets. Higher protein levels in the simulated diets may have resulted from the young trained nilgai selecting higher quality diets than the older wild specimens. Younger nilgai (both wild and trained) generally selected a higher percentage of more nutritious forage than older nilgai (Table 2). Simulated diets of the male calf, 10 months younger than the female, averaged $10.9 \%$ crude protein compared to $9.2 \%$ for the female's diet. The highest crude protein level for trained nilgai (15.6\%) was within the range of $13-16 \%$ suggested by

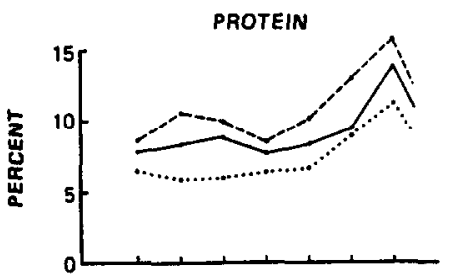

$$
\begin{aligned}
& 16 \\
& 13-\text { OPTIMUM FOR DEER } \\
& 9 \\
& 9 \\
& 6 \\
& 6
\end{aligned}
$$

CALCIUM

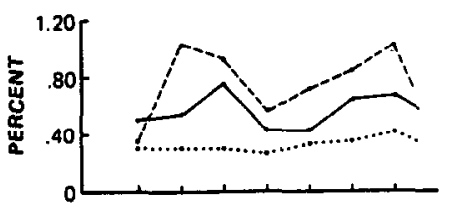

$$
\begin{aligned}
& .64 \\
& .30-\text { RANGE FOR OEER } 3 / \\
& .18-\text { YOUNG BEEF.BULL MAINTENANCE }
\end{aligned}
$$

PHOSPHORUS
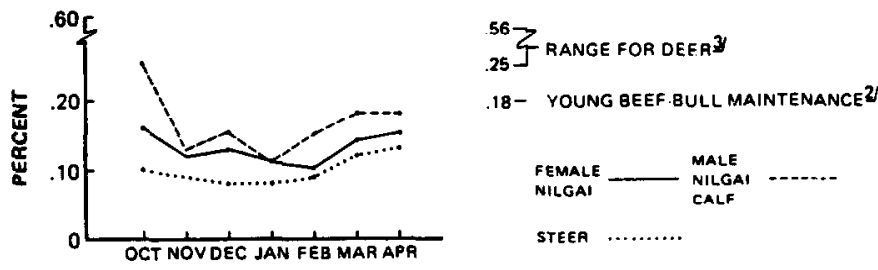

Fig. 4. Nutritional levels in hand simulations of diets selected by 2 trained nilgai and a steer, Norias Division, King Ranch. The nutritional levels compared to levels published for certain big game cattle $(l=$ French et al. 1955; 2 = Dietz 1965; 3 = Magruder 1957). 

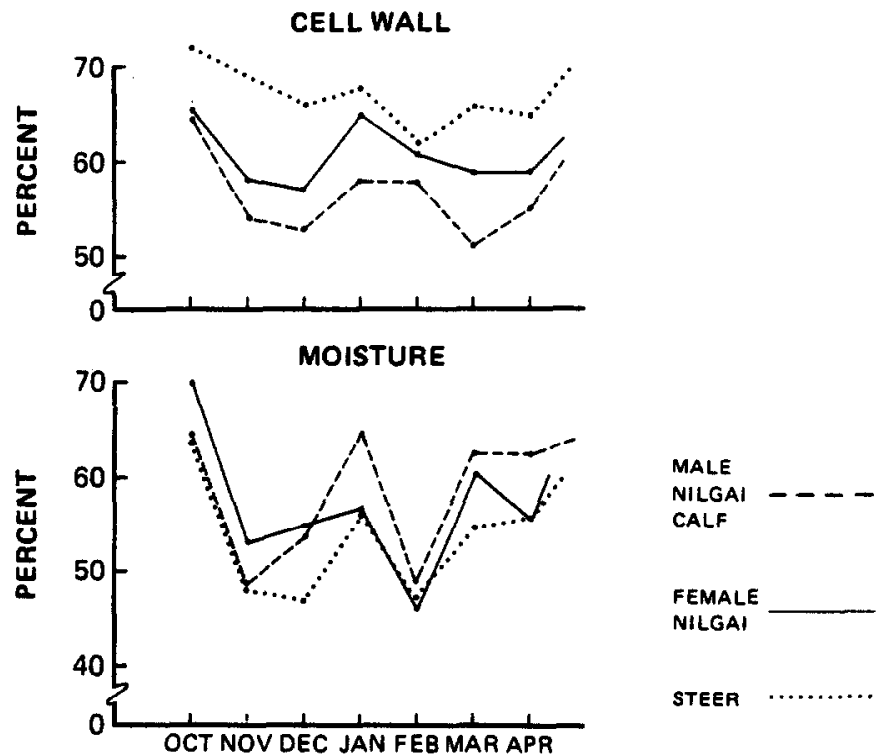

Fig. 5. Levels of cell wall and moisture in hand simulations of diet selected by 2 trained nilgai and a steer, Norias Division, King Ranch.

French et al. (1956) for optimum growth of deer. The low for trained nilgai $(7.9 \%)$ was within the maintenance range of $5.9-13.9 \%$ for various classes of beef cattle (NAS-NRC 1970) and above the minimum of 6-7\% for white-tailed deer (French et al. 1956, Dietz 1965) (Fig. 4).

\section{Calcium}

Simulated diets of the male nilgai calf ranged form $0.36 \% \mathrm{cal}$ cium in October to $1.04 \%$ calcium in April and November. The average amount of calcium was higher in simulations of the calf's diet than the older trained female (Fig. 4). The low level was above the $0.18 \%$ suggested for growth and maintenance of young bulls (NAS-NRC 1970). The range obtained from simulated nilgai diets overlapped the $0.30-0.64 \%$ range for deer (French et al. 1956, Magruder et al. 1957).

\section{Phosphorus}

The soils of Norias are deficient in phosphorus (Reynolds et al. 1953). Phosphorus reached its highest level in simulated fall diets of the trained calf $(0.25 \%)$. Levels in simulations for both trained nilgai $(0.10-0.25 \%)$ were lower than the range $(0.25-0.56 \%)$ suggested for deer (Magruder et al. 1957) and averaged lower $(0.15 \%)$ than suggested for growing beef bulls (0.18\%) (NAS-NRC 1970).

Calcium-phosphorus ratios in simulated diets of trained nilgai ranged from 1.4:1 to 8:1 and average 4.5:1. Rumen samples from wild nilgai had more divergent ratios (2:1 to $11: 1)$, but their average (2.6:1) was more desirable than the average of simulated diets. The ratios in prominent forage species tested during this study were as divergent as $14: 1$.

Calcium is said to interfere with the metabolism of phosphorus when the Ca:P ratio is greater than 5:1 (Dietz et al. 1962, Urness et al. 1971). Of the approximately 100 nilgai necropsied or immobilized and examined, few had visible abnormalities attributable to mineral deficiencies or imbalance. The animals may have obtained minerals around the mineral feeding stations located at water wells and other sites.

Cable and Shumway (1965) concluded that measurement of nutrition in clipped diets of steers was suitable for an indiction of the quality of range forage, but was not suitable for determining nutritional levels maintained by range animals. On ranges such as Norias, where animals have access to supplementary minerals, simulations may be no less reliable than in vivo indices of mineral levels that wild animals maintain. Close comparison between nutritional levels in simulated diets of nilgai and published levels for game animals and cattle indicated the levels estimated were a useful approximation of the relative diet quality among the classes of animals studied.

\section{Diet Quantity}

The dry weight rumen contents of nilgai specimens averaged 2.1, 1.8 , and $1.0 \mathrm{~kg}$ for males, females, and subadults, respectively (Table 4). From day and night field observations nilgai were assigned 3 daily feeding periods. They had 2 diurnal feedings which lasted 4 to $5 \mathrm{hr}$ with prime times between $630-1030 \mathrm{hrs}$. and 1700-1900 hr. Nocturnal feeding appea red casual and was equated to one diurnal feeding to give the 3 feeding periods. An average elapsed time between feedings was estimated to be $7-1 / 2 \mathrm{hr}$. Considering elapsed time and $10 \mathrm{hr}$ passage time of insesta from one feeding through the rumen, $75 \%$ of rumen contents of collected specimens was attributed to one feeding.

Table 4. Number of nilgai and average weight of rumen contents by sex and age class, Norias Division, King Ranch, Texas.

\begin{tabular}{lccc}
\hline & & \multicolumn{2}{c}{$\begin{array}{c}\text { Average kg weight } \\
\text { rumen contents }\end{array}$} \\
\cline { 3 - 4 } Animal class & Number & Green & Air dry \\
\hline Adult males & 869 & 35 & 2.1 \\
Adult females & 876 & 27 & 1.8 \\
All subadults & 404 & 15 & 1.0 \\
\hline
\end{tabular}

IBased upon 1970 census (Sheffield et al. 1971).

${ }^{2}$ Indicated by measurements of 79 nilgai collected.

The above figures applied to the formula cited under Methods gave an estimate of $4.7,4.0$, and $2.3 \mathrm{kgdry}$-weight forage consumed daily by male, female, and subadult nilgai, respectively. The average daily quantity an individual nilgai consumed was $4 \mathrm{~kg}$. The percentage of forage classes in nilgai rumen samples (Table 1) multiplied by the $4 \mathrm{~kg}$ quantity, gave a daily average for individuals of $2.4,1.0$, and $0.6 \mathrm{~kg}$ of grass, forbs, and browse, respectively. The average daily quantity per animal class times the number of individuals per class, products summer, gave an estimate of $8,518 \mathrm{~kg}$ dry-weight forage removed from the range daily by the Norias nilgai herd. Halls (1970) reported that dry-weight forage consumed daily by big game animals and livestock is roughly 2 to $5 \%$ of their live weight. Calculations using $2 \%$, produced forage weight comparable to figures obtained for nilgai (i.e., $214 \mathrm{~kg}$ avg. wt nilgai specimens $\times 2 \%+4.3 \mathrm{~kg}$, compared to 4.7 and $4.0 \mathrm{~kg}$, estimated for adult male and female nilgai based on data from this study).

\section{Feeding Comparisons}

\section{Nilgai vs. Deer}

Herbaceous forage was preferred by nilgai and deer (Table 1). Nilgai preferred grass $(60 \%)$ and deer preferred forbs $(60 \%)$. Both species used mesquite beans heavily but nilgai used slightly more $(9 \%)$ than deer $(4 \%)$. Deer used a greater variety of nutritious supplements than nilgai and did not rely as heavily on any one item. Rumens of deer had supplementary items such as mushrooms, lichens, ball mosses (Tillandsia spp.) and tasajillo fruit (Opuntia leptocaulis). Fewer of those items were found in nilgai rumens and the trained nilgai occasionally selected them. Species prominent in the diet of deer and not nilgai were copperleaf (Acalypha radians), phlox ( $P$ hlox, spp.), herbaceous mimosa (Mimosa strigillosa), sensitivebriar (Schrankia latidens), pricklypear, tasajillo, and lime pricklyash (Zanthoxylum fagara).

When Davis (1951, 1952) studied deer on Norias the nilgai population was small and there was more brushland than during this study. He found the order of food preference for deer was browse, forbs, and grass, respectively. Subsequently, large a reas of Norias were rootplowed and there was a concomitant increase in the nilgai population. Deer became predominately grazers consequently their food habits became more convergent with nilgai and cattle. It cannot be affirmed that competition between nilgai and deer would have been greater today had rootplowing not been done. Nilgai gave evidence of an ability to use browse heavily when more preferred foods were unavailable. It is felt, however, that an 
important factor contributing to the increase in nilgai was the conversion from brush to grassland by rootplowing.

Adaptive and physical differences among nilgai and deer influence their ability to compete for food. The larger nilgai can reach higher than deer for food so they have a deeper vertical food stratum then deer or Santa Gertrudis cattle. Where substantial fences such as the 1.5 meter-high net wire fences on Norias bisect range shared by nilgai and deer, deer have a greater horizontal stratum because, unlike the less agile nilgai, deer can easily negotiate the fences.

The daily amount of air dry forage consumed by a Norias deer $(1.3 \mathrm{~kg})$ and percentages of forage classes in deer rumen samples provided a daily breakdown for deer of $0.3,0.8$, and $0.2 \mathrm{~kg}$ of grass, forbs, and browse, respectively. By comparison, a nilgai consumes $2.4,1.0$, and $0.6 \mathrm{~kg}$ of grass, forbs, and browse (Table 5).

Table 5. Annual percentage and daily quantity of forage classes consumed by 3 species ${ }^{1}$ of animals studied, Norias Division, King Ranch, Texas.

\begin{tabular}{|c|c|c|c|c|c|c|}
\hline \multirow{2}{*}{$\begin{array}{l}\text { Forage } \\
\text { class }\end{array}$} & \multicolumn{2}{|c|}{ Nilgai } & \multicolumn{2}{|c|}{ Deer } & \multicolumn{2}{|c|}{$\begin{array}{l}\text { Santa Gertrudis }{ }^{3} \\
\text { cattle }\end{array}$} \\
\hline & $\%$ & $\mathbf{k g}^{2}$ & $\%$ & $\mathrm{~kg}$ & $\%$ & $\mathrm{~kg}$ \\
\hline Grass & 60 & 2.4 & 23 & 0.3 & 95 & 8.5 \\
\hline Forbs & 25 & 1.0 & 60 & 0.8 & 3 & 0.3 \\
\hline Browse $^{4}$ & 15 & 0.6 & 17 & 0.2 & 2 & 0.2 \\
\hline Total & 100 & 4.0 & 100 & 1.3 & 100 & 9.0 \\
\hline
\end{tabular}

'Average value per individual animal.

${ }^{2}$ Forage air dry.

Jercent derived from feeding performance of a study steer. Total quantity derived from studies underway on Santa Gertrudis cattle in south Texas (M.M. Kothmann pers. comm.)

AAll browse components combined.

\section{Nilgai vs. Cattle}

Throughout the year, the study steer ate grass almost exclusively. It was less selective of plant species and parts than nilgai and appeared more concerned with quantity of intake. It took an average of 1,133 bites per hour while feeding compared to 528 bites for the female nilgai and 264 bites for the male nilgai calf.

During periods of satisfactory range conditions competition between nilgai and cattle for grass was not severe because of the high diversity and amount of grass. Also, their selections of grass did not exactly coincide. They competed strongly, however, for the limited grass available during seasonal lows and droughts.

\section{Interspecific Competition}

The greatest feeding competition occurred between nilgai and cattle for grass, nilgai and deer for forbs, and among all 3 species for browse seed (Table 6). Although forbs constituted a higher percentage of the deer diet than nilgai or cattle diets, the absolute intake of forbs by the latter two species rivaled that of deer. Nilgai actually consumed more forbs than deer (Table 5). The fact that deer relied on high quality forb parts more than high quantity intake mitigated the interspecific competition.

There was strong competition for mesquite beans, perhaps acorns (not available during this study), and other seeds. Low percentages of browse foliage consumed by each of the animal classes and good diversity and quantity of browse year round, mitigated nilgai-deer-cattle competition for browse. Deer maintained higher dietary percentage of browse, nilgai greater absolute quantity of intake, and cattle an equivalent quantity of browse intake to deer (Table 5).

The importance of, and competition for forage classes among the animal species was reflected by their quantity of use equivalents. Santa Gertrudis cattle/white-tailed deer equivalents on Norias were developed by Davis (1952). He considered the seasonal variations in quantity of use of browse, herbs (forbs), and grasses by cattle and deer, and calculated that, on the average, 13 deer ( $45 \mathrm{~kg} \mathrm{wt})$ ate as much as one steer ( $454 \mathrm{~kg} \mathrm{wt}$ ) on a reciprocal forage use basis. This study indicated that equivalent amounts of
Table 6. Preferred forage species of nilgai,' with competition for species among nilgai, ${ }^{2}$ deer $^{3}$ and cattle ${ }^{4}$ designated by seasons, Norias Division, King Ranch.

\begin{tabular}{|c|c|c|c|c|}
\hline Forage species 5 & Spring & Summer & Fall & Winter \\
\hline $\begin{array}{l}\text { Grasses: } \\
\text { Paspalum spp. } \\
\text { Setaria spp. } \\
\text { Cenchrus spp. } \\
\text { Eragrostis spp. } \\
\text { Panicum spp. } \\
\text { Andropogon spp. } \\
\text { Vaseyochloa multinervosa } \\
\text { Aristida spp. } \\
\text { Bothriochloa ischaemum } \\
\text { Leptochloa spp. } \\
\text { Dichanthium annulatum } \\
\text { Sporobolus spp. } \\
\text { Cynodon dactylon } \\
\text { Distichlis spicata }\end{array}$ & $\begin{array}{l}\text { NDC } \\
\text { ND } \\
\text { NC } \\
\text { NC } \\
\text { ND } \\
\text { NC } \\
\text { NC } \\
\text { NC } \\
\text { NC }\end{array}$ & $\begin{array}{l}\text { NDC } \\
\text { ND } \\
\text { NC } \\
\text { NC } \\
\text { NC } \\
\text { NC } \\
\\
\text { NC } \\
\text { NC } \\
\text { NC } \\
N \\
\text { NC } \\
\text { NC }\end{array}$ & $\begin{array}{l}\text { NDC } \\
\text { ND } \\
\text { NC } \\
\text { NC } \\
\text { NC } \\
\text { NC } \\
\text { ND } \\
\text { NC } \\
\text { NC } \\
\text { NC } \\
\text { NC } \\
\text { NC } \\
\text { NC }\end{array}$ & $\begin{array}{l}\text { NDC } \\
\text { NDC } \\
\text { NC } \\
\text { ND } \\
\text { NC } \\
\text { NC } \\
\text { NC } \\
\text { NC } \\
\text { NC } \\
\text { NC } \\
\text { NC } \\
\text { NC } \\
\text { NC }\end{array}$ \\
\hline $\begin{array}{l}\text { Sedges: } \\
\text { Eleocharis spp. } \\
\text { Cyperus spp. }\end{array}$ & $\begin{array}{l}\text { ND } \\
\text { ND }\end{array}$ & $\begin{array}{l}\text { ND } \\
\text { ND }\end{array}$ & $\begin{array}{l}\text { ND } \\
\text { ND }\end{array}$ & $\begin{array}{l}\text { ND } \\
\text { ND }\end{array}$ \\
\hline $\begin{array}{l}\text { Forbs: } \\
\text { Cassia fasciculata } \\
\text { Rhynchosia spp. } \\
\text { Sida spinosa } \\
\text { Clematis drummondii } \\
\text { Solanum spp. } \\
\text { Croton spp. } \\
\text { Gailardia pulchella } \\
\text { Commelina erecta } \\
\text { Phyla incisa } \\
\text { Coreopsis spp. }\end{array}$ & $\begin{array}{l}\text { ND } \\
\text { ND } \\
\text { ND } \\
\text { ND } \\
\text { ND } \\
\text { ND } \\
\text { NDC }\end{array}$ & $\begin{array}{l}\text { NDC } \\
\text { NDC } \\
\text { ND } \\
\text { ND } \\
\text { ND } \\
\text { ND } \\
\text { ND } \\
\text { ND } \\
\text { ND } \\
\text { ND }\end{array}$ & $\begin{array}{l}\text { NDC } \\
\text { ND } \\
\text { ND } \\
\text { ND } \\
\text { ND } \\
\text { ND } \\
\text { ND }\end{array}$ & $\begin{array}{l}\text { ND } \\
\text { ND }\end{array}$ \\
\hline $\begin{array}{l}\text { Browse: } \\
\text { Lycium berlandieri } \\
\text { Prospopis glandulosa } \\
\text { Celtis pallaida } \\
\text { Quercus virginiana } \\
\text { Condalia obovata }\end{array}$ & $\begin{array}{l}\text { ND } \\
\text { NDC } \\
\text { ND } \\
\text { ND } \\
\text { ND }\end{array}$ & $\begin{array}{l}\text { NDC } \\
\text { ND } \\
\text { ND } \\
\text { ND }\end{array}$ & $\begin{array}{l}\text { NDC } \\
\text { ND } \\
\text { ND } \\
\text { ND }\end{array}$ & $\begin{array}{l}\text { ND } \\
\text { ND } \\
\text { ND } \\
\text { ND }\end{array}$ \\
\hline
\end{tabular}

'Order of preference of nilgai by forage classes.

${ }^{2}$ Determined by bite studies with two trained nilgai and identifiable plant parts in rumen samples.

'Determined by identifiable plant parts in rumen samples.

${ }^{4}$ Determined by bite studies with a study steer.

'Plant names are according to Gould 1975.

'N-nilgai; D-deer; C-cattle.

grass were consumed by 1 Santa Gertrudis, 3.5 nilgai, or 28 deer; forbs by 1 nilgai, 1.3 deer, or 3.3 Santa Gertrudis; and browse by 1 nilgai, 3 deer, or 3 Santa Gertrudis.

\section{Summary and Conclusions}

Norias nilgai are grazers, and eat grasses, forbs, and browse in that order. The quantity and quality of forage available strongly influences their food selections. Browse is important to nilgai as supplementary food. They meet their nutritional requirements by selecting nutritious plant parts and changing their selections as dietary items appear, wane, and fluctuate in quality throughout the year.

Nilgai, deer, and cattle differ in their preference for forage classes, plant species, and plant parts, although there is overlap. Differences can be related to size and metabolic rates of the animals as theorized by Bell (1972). Noris cattle, largest of the species studied, select the lowest quality, but ingest the highest quantity of food. Grass was their basic diet and they appeared better able to sustain themselves on grass than nilgai or deer. Nilgai, intermediate in size between cattle and deer, made heavy use of grass and could compete strongly with cattle. Nilgai, however, required a more nutritious diet than cattle and consumed a higher percentage of forbs and browse. Deer, smallest of the study species, required 
the least quantity but high quality of food. They consumed the highest percentage of forbs and browse and lowest percentage of grass.

The large variety and quantity of herbage is a buffer against strong feeding competition, and nilgai, deer, and cattle maintain compatible feeding roles under satisfactory range conditions. Strong feeding competition among them arises when the variety and quantity of herbage diminishes during seasonal vegetation lows and drought. At those times, their adaptive and physical differences and range management play important roles in their ability to compete for food.

The larger, less agile cattle are more adapted to processing large quantities of easily obtainable food, and they are less selective. Nilgai, smaller and more agile than the cattle, are better adapted for selective feeding. The still smaller, more agile deer are better adapted for selective feeding than nilgai or cattle, and fences are not a barrier to their feeding range. Under stressed range conditions cattle must rely on management, nilgai on their feeding versatility and an aerial food strata only they can reach, and deer on their ability to select sequestered food items and survive on lower quantities.

In the absence of current data applicable to Norias that provide substitution rates for dominant range herbivores, a cursory guide of 1:3:28 for cattle, nilgai and deer, respectively, might be considered. The numbers are not reciprocal and are based only on an estimate of the equivalent use of grass (the staple food of cattle). Similarly, one nilgai may supplant 1.3 deer based only on their use of forbs (the staple food of deer).

\section{Literature Cited}

Association of Official Agricultural Chemists. 1970. Official methods of analysis. 1 lth ed. Washington, D.C.

Bell, R.H.V. 1971. A grazing ecosystem in the Serengeti. Sci. Amer. 225:8693.

Buechner, H.K. 1950. Life history, ecology, and range use of the pronghorn antelope in Trans-Pecos, Texas. Amer. Midl. Natur. 43:257-354.

Cable, D.R., and R.P. Shumway. 1965. Crude protein in rumen contents and forage. J. Range Manage. 18:124-128.

Chamrad, A.D., and T.W. Box. 1964. A point frame for sampling rumen contents. J. WildI. Manage. 21:158-164.

Daubenmire, R. 1959. A canopy-coverage method of vegetation analysis. Northwest Sci. 33:43-63.

Davis, R.B. 1951. The food habits of white-tailed deer on the cattle stocked, live oak-mesquite ranges of the King Ranch as determined by analysis of deer rumen contents. M.S. Thesis, Texas A\&M Univ., College Station.

Davis, R.B. 1952. A study of some interrelationships of a native South Texas range, its cattle and its deer. Ph.D. Diss., Texas A\&M Univ., College Station.

Dietz, D.R., R. Donald, R.H. Udall, and L.E. Yeager. 1962. Chemical composition and digestibility of mule deer of selected forage species, Cache La Poudre range Colorado. Colorado Game and Fish Dep., Tech. Bull. 14:89 p.

Dietz, D.R. 1965. Deer nutrition research in range management. Trans. North Amer. Wild. Conf. 30:275-285.
Dinerstein, E. 1979. An ecological survey of the Royal Karnali-Bardia Wildlife Refuge, Nepal. Part II: habitat/animal interactions. Biol. Cons. 16:265-300.

Franki, G.D. 1960. Generalized soil map of Kenedy County, Texas, Soil Cons. Ser., U.S. Dept. Agr. Exp. Sta., College Station.

French, C.E., L.C. McEwen, N.C. Magruder, R.H. Ingram, and R.W. Swift. 1956. Nutrient requirements for growth and antler development in the white-tailed deer. J. Wildl. Manage. 20:221-232.

Gould, F.W. 1975. Texas plants-a checklist and ecological summary. Texas Agr. Exp. Sta., Texas A\&M Univ., College Station. Misc. Pub. 585.

Halk, L.K. 1970. Nutrient requirements of livestock and game. p. 10-17 In: Range and wildlife habitat evaluation - a research symposium. H.A. Paulsen Jr., and E.H. Reid (ed.), USDA, Forest Service. Misc. Publ. 1147.

Long, L.H. (ed.). 1968. The world almanac and book of facts. Newspaper Enterprises Assoc., Inc., New York and Cleveland.

Magruder, N.D., C.E. French, L.C. McEwen, and R.S. Swift. 1957. Nutritional requirements of white-tailed deer for growth and antler development. II. Exp. results of the third year. Pennsylvania Agr. Exp. Sta. Bull. 628:21 p.

Mautz, W.W., and G.A. Petrides. 1971. Food passage rate in the whitetailed deer. J. Wildl. Manage. 35:723-731.

McMahan, C.A. 1964. Comparative food habits of deer and three classes of livestock. J. Wildl. Manage. 28:798-808.

National Academy of Sciences-National Research Council. 1970. Nutrient requirements of beef cattle. No. 4.

Ramsey, C.W. 1969. Ṫexotics. Texas Parks and Wildl. Dep. Bull. 49.

Reynolds, E.B., J.M. Jones, J.H. Jones, J.F. Fudge, and R.J. Kleberg, Jr. 1953. Methods of supplying phosphorus to range cattle in south Texas. Texas Agr. Exp. Sta., Texas A\&M Univ., College Station.

Sheffield, W.J., E.D. Ables, and B.A. Fall. 1971. Geographic and ecologic distribution of nilgai antelope in Texas. J. Wildl. Manage. 35:250-257.

Urness, P.J., W. Green, and R.K. Watkins. 1971. Nutrient intake of deer in Arizona chaparral and desert habitats. J. Wildl. Manage. 35:469-475.

U.S. Weather Bureau. 1969. Climatological data, Texas. U.S. Dep. Comm., Washington D.C. Vol. 74.

U.S. Weather Bureau. 1970. Climatological data, Texas. U.S. Dep. Comm., Washington D.C. Vol. 75.

U.S. Weather Bureau. 1971. Climatological data, Texas. U.S. Dep. Comm.. Washington D.C. Vol. 76.

U.S. Geological Survey. 1952. South of Potrero NW., Texas. Topo. map. Fed. Center Denver, Colo.

U.S. Geological Survey. 1956. Rosita Lake NE, Texas. Topo map. Fed. Center, Denver, Colo.

Van Soest, P.J., and R.H. Wine. 1967. Use of detergents in the analysis of fibrous feeds. IV. Determination of plant cell-wall constituents. p. 50-55. In: J. Assoc. Off. Agric. Chem. 50:242 p.

Wallmo, O.C. 1951. Fort Huachuca wildlife area investigations. Arizona Game and Fish Dep. Proj. No. W-46-R-1.

Wallmo, O.C. and D.J. Neff. 1970. Direct observations of tame deer to measure their consumption and natural forage.p. 107-109 In: Range and wildlife habitat evaluation-a research symposium. H.A. Paulsen, Jr. and E.H. Reid (ed.), USDA, Forest Service. Misc. Publ. 1147.

Watts, C.R. 1964. Forage preferences of captive deer while free ranging in a mixed oak forest. M.S. Thesis, Pennsylvania State Univ., University Park. 